\title{
2 \\ Irregularised citizenship, free movement and territorialities
}

If all the Gypsies were to steal, Tour Eiffel would disappear from 'Sarkozy versus Gypsy' sung by VAMA, featuring Ralflo, as a protest against the 2010 expulsions of Roma from France, quoted in Romea.cz, 2010

\section{Introduction}

In her 2007 journal article, Linda Bosniak argued normatively that all residents in liberal democratic states should have equal rights on the same territory irrespective of their formal legal status: she called this the principle of 'ethical territoriality' (Bosniak, 2007). In practice, policies and laws of different states have oscillated between granting a broader scope of rights for migrants at one extreme, and restricting the rights of some citizens at the other. This chapter offers a descriptive enquiry into restrictions on ethical territoriality and its clash with the other meaning of territoriality: the ability of the state to exercise its sovereign power over its territory (Bosniak, 2007: 404). To investigate the clash between these two meanings of territoriality, the chapter highlights the case of trans-border minorities and minorities that have been present on a territory before current borders were formed. It specifically examines how states move away from the ideal of ethical territoriality and deem not only migrants but some of their citizens as having 'less-than-complete-membership' (Bosniak, 2007: 392) with a position closer to that of foreign residents. Echoing Nyers' (2019) theory on irregular citizenship, the chapter examines acts of sovereignty (Nyers, 2006) and how states, through such acts, irregularise the citizenship of marginalised minorities and 
restrict some of the rights they should have as citizens (van Baar, 2016; Sardelić, 2017b; Nyers, 2019).

This chapter first looks at how states restrict the free movement of Roma in the enlarged and enlarging EU and justify this restriction by abiding with broader universalist principles and protecting the rights of all citizens. I show that this was the case in the debates on EU citizenship as well as the visa liberalisation for the Western Balkans. As a first case study, the chapter analyses the expulsions of Romani Bulgarian and Romanian citizens from France in the summer of 2010. It continues with an examination of the CJEU case Dano v. Jobcenter Leipzig (C-333/13, henceforth the Dano case) of 2014. In this case, the court was seemingly neutral towards all citizens, including Roma. However, the chapter shows how the court's decision led to public discourses that claimed it was Roma in particular who needed to have their rights limited in regard to free movement. The chapter then presents two interrelated cases where marginalised minorities were either prevented from leaving the country where they were citizens or not allowed to stay in the country where they had lived for most of their lives.

The main argument of this chapter is that the restriction of freedom of movement needs to be looked at within a broader context of restricting the rights of marginalised citizens, rather than in terms of problematic migration practices. I claim that restricting the rights of Romani individuals who are mobile falls in the same category as restricting the rights of Indigenous people in Australia under the 2007 Northern Territory Emergency National Response Act or the so-called Intervention (Altman and Hinkson, 2007; Calma, 2009; Watson, 2011; Armillei and Lobo, 2017). Both were based on a misconception of the cultural characteristics of marginalised minorities allegedly in conflict with the norms of human rights guaranteed by liberal democratic states.

\section{Imagining nomadism: migration or the right to free movement?}

Whilst no country in the world at this point fully subscribes to the principle of ethical territoriality, there have been trends in different regions that approximate rights of certain foreigners to those of 
citizens (Kostakopoulou, 2008). Examples of such approximations include the 2004 Citizens' Rights Directive (Maas, 2013) and the 2003 Long-Term Residence Directive (Acosta Arcazaro, 2015) which arguably speak to notions of postnational citizenship (Soysal, 1997) in the EU. Nevertheless, this chapter aims to show that such approximations retain tensions as to the level of national citizenship possible and how they can even support inequalities among national citizens. At the same time, when the states are moving towards ethical territoriality with a specific category of foreigners, they are producing new practices that restrict the rights of some other foreigners and even their own citizens.

The restriction of rights for certain citizens echoes the debate between Will Kymlicka and Susan Moller Okin (Okin, 1999) on multiculturalism versus feminism, especially the question of whether multiculturalism and specific practices of minorities limit the freedom of minorities within minorities, for example minority women and children. However, in the case of Romani minorities and the right to free movement, the multiculturalism debate was twisted into another direction: it was no longer about a practice of limiting special group rights, but about restricting rights that all citizens should possess.

Historically, as well as in the contemporary context, states have legitimised the restricting of universal rights of Roma as a means to address their alleged cultural characteristics: that is, their nonsedentary lifestyle or nomadism (Lucassen et al., 1998; van Baar, 2015; Donert, 2017). Indeed, there have been cases of Romani minorities, especially Irish and British Travellers, who have defended a (semi-)nomadic lifestyle as their cultural right (O'Nions, 2011). However, in today's Europe most Roma are not nomadic (O’Nions, 2011: 378), yet still the representation of Roma as nomads persists and has consequences for legal policies and practices.

Even the most paradigmatic ECtHR case, Chapman $v$. the United Kingdom (2001), on the right to a nomadic lifestyle, in fact primarily dealt with the right to equal access to housing. The representative of the ERRC commented that this is where the importance of the case lies: 'At first sight, these cases appear to be only of relevance to those European countries where Roma continue to live a predominately nomadic way of life. However, in fact the cases raise issues of significance for all Roma' (Clements, 2001). In Chapman $v$. the United Kingdom, the applicant Sally Chapman sought a permit 
to place her family caravan on the land she owned. The local authorities refused the permit. The statistics presented in the case showed that whilst 80 per cent of non-Roma applicants got permits to build their houses on their land, only 20 per cent of Romani applicants were allowed to place caravans on their land. As Clements (2001) argued, the case was not primarily about the special rights of a specific Romani group, but about the right not to be discriminated against under supposedly neutral laws that do not take the special position of Romani minorities into account.

State control measures towards Roma on account of their alleged nomadism have a long-standing history (van Baar, 2011). For example, during the period of the Enlightenment under the rule of Maria Theresa (between 1740 and 1780), the Habsburg monarchy adopted a number of decrees with the intention to assimilate Roma and include them as new but equal sedentary citizens of the monarchy. The decrees included the prohibition of nomadism, the prohibition of marriage between Romani individuals, and the removal of Romani children from their families and their placement in peasant families so that they would learn the ways of sedentary families (Barany, 2002: 93). In the socialist period, a number of states also took the approach of controlling the movement of their Romani citizens. As Donert uncovered (2017: 133), in socialist Czechoslovakia 46,000 Roma were identified as nomads and conscripted into the 1959 Nomad Register, although most of them did not live a nomadic lifestyle. Although the state officially opposed nomadism, it relocated Romani individuals from one part of the federation to another. Most Roma from the Czech territories were killed during World War II, which meant that in post-war Czechoslovakia a much larger number of Roma lived in the Slovak part. As the Czech part became industrialised, the government introduced a policy of relocating Slovak Roma to the Czech Republic in the Czechoslovak Federation, so that they could be evenly distributed and not concentrated in only one part (Kochenov, 2007). This governmental decision had significant consequences for the citizenship status of relocated Roma (see Chapter 4).

In the former Yugoslavia, a similar collective relocation of Romani minorities occurred after the devastating 1963 earthquake in Skopje, which resulted in much of the city being rebuilt. The reconstruction of Skopje also dismantled a part of the centuries-old Romani 
settlement Topaana in the centre of Skopje, and the local authorities gave its inhabitants two options, as the historian David Crowe (2007: 224) commented:

Shuto Orizari began as a temporary American-built Quonset hut community in the aftermath of an earthquake on July 26, 1963 that destroyed three-quarters of the Macedonian capital and left 200,000 homeless. Reconstruction of the old Rom quarter Topana, entailed 'the addition of two intersecting freeways' and officials gave Gypsy leaders two choices: they could move into new integrated neighbourhoods, or they could move into their own suburb on the outskirts of Skopje.

Shuto Orizari, colloquially known as Shutka, later became a model of multicultural coexistence in multi-ethnic Skopje, usually without showing any historical reflection of its establishment as a temporary campsite built with American donations. The inhabitants of Topaana were not nomads but had lived there for centuries, yet the prevailing image of Roma as nomads made it possible to design a policy according to which they were able to be removed from the centre of the city. This predominantly affected the long-standing Romani community in Skopje (Sardelić, 2018). A similar relocation, indirectly sponsored by the EU, took place in the Serbian capital, Belgrade. Roma who lived under the Gazela bridge were relocated to other informal settlements around Belgrade while the bridge was being reconstructed with the support of the European Bank for Reconstruction and Development and the European Investment Bank. As van Baar (2016: 215) notes, in order to enhance the mobility of all EU citizens and connect them with citizens of EU candidate countries, Roma who lived under the 'connecting bridge' had to be forcedly relocated.

Despite available data showing that most Roma are sedentary and are no more mobile than majority populations (Cahn and Guild, 2010), the mass media as well as much research focus on the small population of Romani migrants (Balch et al., 2013). Although most of the academic literature is critical of discourses and practices faced by Roma as migrants (Magazzini and Piemontese, 2019; Messing, 2019; Leggio, 2019; Humphris, 2019), the unrelenting focus on Romani migration also contributes to the reproduction of the image of the Romani migrant. In my previous work I have argued that 
whilst very few Roma are migrants, and it is questionable whether there is such a thing as Romani migration, the politics around Romani migration certainly exists (Sardelić, 2019b). This has become especially clear in debates on the free movement of EU citizens.

Among the most celebrated achievements of the EU were the 2000 Charter of Fundamental Rights (EU, 2012) and the 2001 Citizens' Rights Directive or EU Free Movement Directive as it is sometimes named (EU, 2004, henceforth the Citizens' Rights Directive). Both documents were EU legal manifestations to bring the EU closer to the ideal of ethical territoriality recognising rights of residents and citizens alike living in all Member States. The major breakthrough that both documents brought was the extension of social and economic rights to all citizens living in another EU Member State than their own. The free movement of EU citizens was initially conceptualised as a free movement of workers in the 1957 Treaty of Rome, which through Article 48 prohibited the discrimination of workers in question: 'Such freedom of movement shall entail the abolition of any discrimination based on nationality between workers of the Member States as regards employment, remuneration and other conditions of work and employment' (Treaty of Rome 1957, a. 48). However, it was only with the 2004 Citizens' Rights Directive that the rights of EU citizens were statutorily decoupled from the economic logic and labour market demands of an individual EU Member State (Carrera, 2005). With the EU Charter of Fundamental Rights and the 2004 Citizens' Rights Directive, the freedom of movement was transformed into the fundamental right of all EU citizens and their family members (even if the family members were third-country nationals). In Article 27(1) of the Citizens' Rights Directive, there is an explicit prohibition of the restriction of the free movement rights based on economic demand: 'Subject to the provisions of this Chapter, Member States may restrict the freedom of movement and residence of Union citizens and their family members, irrespective of nationality, on grounds of public policy, public security or public health. These grounds shall not be invoked to serve economic ends' (EU, 2004, a. 27). The expulsion of EU citizens and their families can occur only when there are serious threats to public health, public policy and public security, and the Directive included several procedural safeguards in Article 15 against such expulsions. 
The perceived mobility practices place Roma with notional EU citizenship status close to the position of foreigners as they are stripped of their citizenship rights. More concretely, even in cases where Roma were EU citizens, the host states have used their 'acts of sovereignty' (Nyers, 2006) to irregularise them as EU citizens (Sardelić, 2017b) and appropriate their rights to those of third-country nationals (van Baar, 2016). It is important to note that the question of mobility and nomadism is never a stand-alone question but is always connected to the bigger puzzle of what rights citizens who are mobile have in a certain territory. States have securitised and criminalised the alleged problematic mobility practices of Roma in order to justify restricting their free movement rights (van Baar, 2015, 2019; Carrera and Faure Atger, 2010; Sardelić, 2017b). The criminalisation of Romani migration is not only perpetuated by states themselves, but has also often been uncritically reinforced in the reports of international organisations, as for example in the following 2016 report from the EU's Agency for Law Enforcement Cooperation (EUROPOL) on human trafficking:

Criminal networks of Roma ethnicity are extremely mobile. Young women and minors of this group are especially vulnerable to exploitation and trafficking, which is sometimes arranged by their own families. This happens quite frequently in cases of child trafficking, where parents and close relatives are part of the recruitment circle. Destination countries for trafficked minors from Roma communities are mainly the United Kingdom and France, where they are subjected to sexual exploitation, labour exploitation, forced begging, petty crimes, and to a lesser extent the systematic defrauding of the social security and welfare benefit systems. The perpetration of property crimes is the main activity and source of income. Women and minors are mainly engaged in street crimes such as pick pocketing, bag-snatching and shoplifting in crowded and tourist areas, while men are in charge of the logistical and organisational management of the criminal activities (e.g. document forging, recruitment of new members, trade of high value vehicles and management of belongings). (EUROPOL, 2016: 18)

Two clear examples of such entanglement between mobility rights and alleged problematic nomadism took place during the so-called l'affaire des Roms (Carrera and Faure Atger, 2010; Balch et al., 2013) and in the subsequent 2014 CJEU decision in the Dano case. 
In the summer of 2010, French authorities initiated a plan instated by the then president, Nicolas Sarkozy, in a speech in Grenoble (La Croix, 2010). The speech was connected to a general crackdown on crime and irregular migration, but it shifted its attention to Romani EU citizens. In August 2010 French authorities expelled a thousand Romani individuals who were Romanian and Bulgarian citizens (BBC, 2010) after dismantling their informal settlements, and between 2009 and 2011 up to twelve thousand Roma were expelled each year (Ram, 2014a: 207). The justifications for dismantling these settlements were not only poor living conditions, but also the perception that these were the 'breeding grounds' for criminal activity of mobile groups, such as human trafficking and the exploitation of women and children (Gunther, 2013; Aradau et al., 2013; Faure Atger, 2013; van Baar, 2015). In August 2010 the French Ministry of the Interior published a circular that included guidelines allowing the police to specifically target Roma from other EU Member States when demolishing informal settlements. When the circular was leaked to the press, later documents omitted a reference to Roma but did not prevent the demolition of their settlements (Carrera and Faure Atger, 2010: 4).

In 2010 a provisional measure was still in place that restricted the right to work of Bulgarian and Romanian citizens in other EU Member States. This measure was enacted so that the citizens of the new EU Member States who joined in 2007 would not migrate en masse to other EU countries in order to seek employment. However, the 2004 Citizens' Rights Directive was already in place, and this provided a safeguard against the expulsion of those Romanian and Bulgarian citizens who were already in other EU Member States. Any restriction on free movement had to be framed in connection to a threat to public policy, public security and public health, and not simply in terms of formal economic activity. With the dismantling of informal settlements, French authorities actively irregularised the status of Roma EU citizens of other Member States in order to create grounds for expulsion (Sardelić, 2017b). However, it became clear very soon that these expulsions were not made on a case-by-case basis, but were collective and therefore in breach of Article 19 of the EU Charter of Fundamental Rights and the Citizens' Rights Directive itself (van Baar, 2016). 
Vivian Reding, who at the time was the Vice President of the European Commission and the Commissioner in charge of the Directorate for Justice, criticised France heavily over the collective expulsion of EU citizens of Romani background (Reding, 2010a; Balch et al., 2013; and Ferreira, 2019) which also constituted a breach of the EU's 2000 Race Equality Directive (O’Nions, 2011). This Directive prohibits indirect discrimination on the basis of race or ethnicity. Following Article 258 of the Treaty on the Functioning of the European Union, the European Commission announced an infringement procedure against France on 15 October 2010 because it was not abiding by the fundamental legal principles of the EU. However, by 19 October the European Commission had revoked its decision, and it did not start the infringement procedure against France since it claimed that the French authorities had made official commitments to halt the collective expulsions of Roma from France (Reding, 2010b).

Whilst collective expulsions stopped in the eyes of the media, the French Office for Immigration and Integration continued its 'voluntary repatriation' project funded by the European Commission with a budget of $€ 34,760,077$ (Sardelić, 2017b: 339). Each Bulgarian and Romanian citizen who decided to 'voluntarily' leave France to return to their country of citizenship was awarded a one-way ticket and $€ 300$ in cash bursaries as a social inclusion measure for integration back into their country of origin. At the end of the project in 2012, France and Romania signed a repatriation agreement: 'France and Romania have signed a deal on the voluntary repatriation of Roma to Romania, with both sides saying that 'time' and 'patience' were needed to solve Roma migration problems (Euractiv, 2012; my emphasis). The European Commission report evaluated the project on voluntary repatriation as positive: '[t]he Project has had a positive impact: it facilitated return on a voluntary basis, ensuring the rights of migrants and initiating both sustainable return and reintegration in the individuals' country of origin. With the financial allowance, migrants were able to establish a new economic activity in their home country' (European Commission, 2011d).

Whilst it is not clear from the project description whether France's assisted voluntary return programme for Romanian and Bulgarian citizens was funded by the European Commission, the logic of returning them to their countries of origin was very similar to that 
of the return of third-country nationals funded by the European Return Fund. It received heavy criticism from civil society and Romani individuals themselves (Faure Atger, 2013). For example, in its punk rock song 'Sarkozy versus Gypsy', quoted in the introduction to this chapter, the Romanian band VAMA featuring Ralflo, with Romani members, mocked such politics with the following lyrics:

We're looking for the better way

But you decide we cannot stay ...

You take the right to dream, to work ...

Three hundred euros won't buy hope ...

The fingerprint is not our soul

We're human beings first of all ...

If all the gypsies were to steal ...

Tour Eiffel would disappear ...

The world belongs to all the people

Gypsy people is not people?

(VAMA featuring Ralflo, 2010, quoted in Romea.cz, 2010)

Further responses by the European Commission to the European Parliament, the EU Council, the European Economic and Social Committee and the Committee of Regions led to the establishment of the EU NRIS Framework (European Commission, 2011b: 173). Whilst this was a response to the approach France took towards Romani migrants (Carrera et al., 2019), it did not address the position of Romani migrants per se but rather reinstated the logic that each EU Member State should primarily be responsible for the integration of its own Romani citizens (Magazzini and Piemontese, 2019). As Dragos Ciulinaru (2018: 1059) explains, there was a 'shift from protection against discrimination to the issue of integration'. In 2013 the EUs NRIS Framework became operational (for more details see Chapter 1). In parallel with the operationalisation of this strategy, however, the CJEU dealt with the Elisabetta and Florin Dano $v$. Jobcenter Leipzig case and reached a decision in November 2014. The Dano case concerned a Romanian citizen and her son who had moved to Germany under the Citizens' Rights Directive. According to the data the CJEU possessed, Elisabeta Dano had had only three years of primary schooling, did not have a profession, had limited knowledge of the German language and was not formally working or seeking formal work in Germany, but was economically supported by her sister. In its discussion of the prohibition of discrimination 
on the basis of nationality, the court omitted any reference to her ethnicity or possible discrimination she might have faced in her country of citizenship as a basis for being mobile. However, the CJEU did reach the decision that since she was not seeking formal work, in accordance with Articles 14 and 24 of the Citizens' Rights Directive, Germany was not obliged to provide any social assistance to her or her son: 'It is apparent from the documents before the Court that Ms Dano has been residing in Germany for more than three months, that she is not seeking employment and that she did not enter Germany in order to work. She therefore does not fall within the scope ratione personae of Article 24(2) of Directive 2004/38' (Dano v. Jobcenter Leipzig 2014, para. 66).

The court's decision in the Dano case became prominent in the debates about the UK's membership in the EU, popularly known as Brexit. As Euractiv reported: 'EU Member States can block jobless immigrants from receiving specific welfare benefits, Europe's top Court said on Tuesday (11 November), in a ruling likely to aid British Prime Minister David Cameron's efforts to tackle so-called "welfare tourism"' (Euractiv, 2014). Like the CJEU decision in Dano, Euroactiv made no reference to Dano's Romani ethnicity. However, the article did include a photo of a beggar on the street with the caption: 'Roma panhandler in Sweden, 2013' (Euractiv, 2014). There was no discussion on how the photo of a Romani beggar allegedly from Sweden related to the Dano case, if it was not for the previous reports that mobile Romani migrants commit social assistance fraud as 'welfare tourists' (Geddes and Hadj Abdou, 2016). Most of the newspaper articles on welfare tourism ignored practices such as 'dental tourism' (Österle et al., 2009), whereby British citizens travel to Eastern European countries for cheaper dental healthcare. Yet the British tabloids did identify Elisabeta Dano as a Roma and even labelled her a 'gypsy': 'Wrapped up warm for a day out in town, this is the Roma gipsy whose refusal to work has spurred a crackdown on benefits tourism. Elisabeta Dano, 25, has found herself at the centre of a landmark European case, which has apparently given Britain the green light to block welfare claims from migrants who refuse to work' (Bentley, 2014). Whilst the CJEU wanted to avoid any reference to ethnicity, the media, especially the British tabloids, were explicitly stereotypical in this manner. The tabloids also quoted 
from her statement that she was a babysitter for her sister, yet this was not considered to be work as it was informal.

Besides being portrayed as benefit tourists, Romani migrants, particularly those from non-EU countries, have been increasingly depicted as 'bogus asylum seekers'. Roma had already been represented as asylum seekers before the 2004 EU enlargement (Clark and Campbell, 2000; see also Chapters 1 and 5), but the main discussion on restricting the rights of Romani asylum seekers emerged during the process of the Schengen visa liberalisation for the Western Balkan countries. The Schengen visa requirements for the three post-Yugoslav countries (Serbia, Montenegro and North Macedonia) were lifted in late 2009, and, in late 2010 they were lifted for Albania and BIH also (Kacarska, 2015: 363). As stated by one of the reports from the European Migration Network, an EU-funded group, on the visa liberalisation's impact on destination countries: 'Several Member States of the EU (Germany, Sweden, Belgium) have notified that within a year from launching visa liberalisation had to deal with significantly increased, doubled and tripled asylum applications. Majority of asylum applications belonged to minority groups of Roma and ethnic Albanians, who appeared less integrated within local societies, having fewer chances for improving living conditions' (European Migration Network, 2018: 5).

After the change in the visa regime for the countries in the Western Balkans, the number of asylum seekers from these countries did indeed significantly increase: in 2009, before the visa restrictions were lifted, EU Member States received 5,460 asylum applications from Serbia, and, by 2014 they had received 30,810 applications from the same country. More than three quarters of these asylum applications were received in Germany (Kummrow, 2015: 21). As many as 90 per cent of the individuals who applied for asylum from the Western Balkan countries self-identified as Roma, though it was not clear whether these individuals were in fact all Romani or whether they included non-Romani asylum seekers wishing to secure asylumseeking status (Sardelić, 2018: 499).

However, the increased number of asylum seekers caused a heated debate in the European Parliament, which in September 2013 voted on a visa-free suspension mechanism that would reintroduce the 
visa regime for the Western Balkan countries should the number of asylum seekers continue increasing. The mechanism was legally introduced through EU Regulation 1289/2013: 'This Regulation should establish a mechanism for the temporary suspension of the exemption from the visa requirement for a third country listed in Annex II to Regulation (EC) No. 539/2001 ("the suspension mechanism") in an emergency situation, where an urgent response is needed in order to resolve the difficulties faced by at least one Member State, and taking account of the overall impact of the emergency situation on the Union as a whole.' As Article 2 of the Regulation specified, the suspension mechanism could be enacted in the following scenarios:

A substantial and sudden increase in the number of: (a) nationals of that third country found to be staying in the Member State's territory without a right thereto; (b) asylum applications from the nationals of that third country for which the recognition rate is low, where such an increase is leading to specific pressures on the Member State's asylum system; (c) rejected readmission applications submitted by the Member State to that third country for its own nationals. (EU, 2013, a. 2)

As Euractiv reported, '[a] mechanism allowing the suspension of visa-free travel for third countries was adopted by the European Parliament last week, but controversial legal issues remain over the increasing problem of "fake" asylum-seekers, often Roma from the Western Balkan countries'. The article continued: 'Several EU countries were affected negatively by the visa liberalisation policy. In particular, a wave of asylum-seekers from Macedonia and Serbia, mainly of Roma or Albanian ethnicity, hit Sweden, Belgium and Germany' (Milevska, 2013). The debate in the European Parliament highlighted that the Western Balkan countries had to strengthen their minority and human rights protections should they want to keep a visa-free regime for the Schengen zone. However, such an approach had an adverse effect. Serbia, for example, started putting up billboards with the message 'I do not want to seek asylum in the European Union' at the border controls in Serbian, Albanian and Romani languages (Sardelić, 2018: 499).

North Macedonia went one step further and started blocking its own Romani citizens from leaving their country, which was against Article 13 of the Universal Declaration of Human Rights (1948). 
As reported by several international NGOs (such as the ERRC), a number of Romani individuals were not allowed to leave North Macedonia if they were identified as potential asylum seekers. Their passports were marked with an 'AZ' stamp which indicated that the holders should not be allowed to leave the country. Instead of introducing a comprehensive and adequate minority protection framework, the countries in question responded to the EU institutions by violating the human rights of ethnic minority citizens in order to preserve the rights of free movement for all other citizens: 'The [North Macedonian] Government argued that the passport revocation measure was necessary to prevent or minimise the risk of individuals violating the immigration laws of other countries, thus damaging the country's reputation' (ERRC, 2014). In 2014 the Constitutional Court of Macedonia deemed the racial profiling taking place on the border unconstitutional, as well as the law on travel documents that permitted certain citizens to exit their own country (ERRC, 2014).

All the cases on the free movement restriction of Romani minorities reveal the discrepancy between ethical territoriality and the other meaning of territoriality, referring to a space where states can practise their sovereign power. The ways in which the states deal with alleged problematic types of mobility and migration are myopic: these cases show how expanding rights for all can effectively limit such rights for certain minorities despite the fact that they are actual citizens themselves. The invisible edges of citizenship reinforce the perception of Romani individuals as migrants rather than citizens and position them at the fringes of citizenship. However, it is a debate about citizenship rights that should transcend the debate about a particular migration or mobility pattern.

\section{Irregularising citizenship globally: the Intervention in Australia}

In his book Irregular Citizenship, Immigration, and Deportation, Nyers (2019) showed that processes of legal status irreguralisation do not apply only to migrants in particular countries, but also to citizens with a migrant background even if they have never been migrants themselves. The Romani individuals whose freedom of 
movement was limited fall into the category of irregularised citizens rather than migrants. It was the rights they possessed as citizens that were infringed in all the cases analysed, although the discussion mainly focused on the portrayal of Romani individuals in question primarily as migrants. In this case, states ascribed nomadism as a specific and essential characteristic of Romani culture that needed to be controlled.

In contrast to Nyers, this chapter claims that citizenship status can become irregularised even in cases where minorities predate the current borders and cannot be conceived as having migrant status at all. In 2013 around 20,000 former Yugoslav citizens of Romani background became at risk of statelessness (see Chapter 4) even though they had never crossed a border that was internationally recognised at the time, as the post-Yugoslav states' borders were established later (Sardelić, 2017b). In general, Roma are rarely regarded as a minority that predates the borders of the Westphalian state order, and are not classified as Indigenous (Olivera, 2012), although there are records of the presence of Roma in Europe before current states emerged (Crowe, 2007). However, citizenship irregularisation does appear also in cases of Indigenous citizens, who can be deprived of rights in a similar manner to Romani citizens in Europe. I examine this claim through an analysis of the 2007 Northern Territory Intervention enacted by the Australian federal Government. The Intervention targeted specifically Indigenous communities in the remote areas of the Northern Territory in Australia.

The Northern Territory Government held an inquiry that resulted in a report entitled Little Children are Sacred (Wild and Anderson, 2007). The report was published in mid-July 2007 and dealt with the disadvantages Aboriginal people face in remote areas of the Northern Territory. Its main focus, however, was on the alleged sexual abuses that children suffered because of these disadvantages, and also on the lack of governmental control over Indigenous communities. The inquiry research team consulted forty-five Aboriginal communities, who suggested possible means of addressing child abuse in these communities, such as: 'dialogue, empowerment, ownership, awareness, healing, reconciliation, strong family, culture, law' (Wild and Anderson, 2007: 15). The team then designed a number of long-term sustainable principles for protecting women and children in the remote Indigenous communities. Among these 
principles, the most important were the improvement of governmental services to remote Aboriginal communities, the recognition of diversity and possible barriers to dialogue, and authentic consultations between the Aboriginal communities and the Northern Territory Government as well as the Australian federal Government. The report stressed the urgency of these measures, recommending that: 'Aboriginal child sexual abuse in the Northern Territory be designated as an issue of urgent national significance by both the Australian and Northern Territory Governments, and both governments immediately establish a collaborative partnership with a Memorandum of Understanding to specifically address the protection of Aboriginal children from sexual abuse. It is critical that both governments commit to genuine consultation with Aboriginal people in designing initiatives for Aboriginal communities' (Wild and Anderson, 2007: 22).

With no immediate response by the Northern Territory Government to the Little Children are Sacred report, the Australian Government took the initiative and introduced the 2007 Northern Territory National Emergency Response Act (henceforth the Intervention Act). The Intervention Act was introduced by the Liberal government of John Howard in a pre-election period, but the measures continued after Kevin Rudd's Labour government came into power. The Intervention started in the year the UN passed the Declaration on the Rights of Indigenous Peoples with the opposition of Australia, New Zealand, US and Canada (O'Sullivan, 2020) and continued in 2008, at the same time as Rudd issued a governmental apology for the 'Stolen Generations', the children from the Aboriginal communities who were forcedly removed from their families by the Australian governments and church missions until the late 1960s (Barta, 2008; Moses, 2011).

As noted by a number of scholars and activists (Altman and Hinkson, 2007; Watson, 2011; Macoun, 2011; Armillei and Lobo, 2017), the Intervention Act took up the sense of emergency in the Little Children are Sacred report but ignored its recommendations about informing, consulting and obtaining proper consent from the Aboriginal communities on the matter. Section 132 of the Intervention Act proclaimed its content as 'special measures' and stated, '[t]he provisions of this Act, and any acts done under or for the purposes of those provisions, are excluded from the operation of Part 2 of the Racial Discrimination Act 1975' (Northern Territory National 
Emergency Response Act 2007, para. 132). Part 2 of the Racial Discrimination Act 1975 includes the 'prohibition of racial discrimination' (Racial Discrimination Act 1975, Part 2). This part refers to paragraph 4 of Article 1 of the 1969 International Convention on the Elimination of All Forms of Racial Discrimination:

Special measures taken for the sole purpose of securing adequate advancement of certain racial or ethnic groups or individuals requiring such protection as may be necessary in order to ensure such groups or individuals equal enjoyment or exercise of human rights and fundamental freedoms shall not be deemed racial discrimination, provided, however, that such measures do not, as a consequence, lead to the maintenance of separate rights for different racial groups and that they shall not be continued after the objectives for which they were taken have been achieved. (UN, 1969, a. 1.4)

The special measures and the exception clause of the Racial Discrimination Act 1975 were revoked so that the Intervention Act could specifically target Aboriginal communities in the Northern Territory. Among other measures, the Intervention Act introduced additional control over alcohol consumption (Part 2) and special filters on publicly funded computers (Part 3) in order to limit pornography access, five-year township leases for the land previously owned by the Aboriginal communities (Part 4) and finally an income management system (Article 126) to control how individuals spent their welfare benefits. As some scholars argued, the abolition of some of the previous successful programmes - such as the Community Development Employment Projects - made more Indigenous individuals dependent on social benefits (Perche, 2017). Overall police presence was increased in the Aboriginal communities, but at the same time, infrastructure (like medical facilities) was not significantly improved as the report recommended. The special measures over the remote Northern Territory continued after the Intervention Act was no longer in force, as a result of the Stronger Futures in the Northern Territory Act 2012 introduced by the Labour government in 2012 (Baehr and Schmidt-Haberkamp, 2017; Perche, 2017). The key change, though, was that this Act no longer targeted Indigenous communities directly (by suspending the Racial Discrimination Act 1975) but focused on disadvantaged communities (Stronger Futures in the Northern Territory Act 2012). Yet all the key elements of the 
Intervention Act remained intact despite the claim in the Act that it was supposed to be temporary (Baehr and Schmidt-Haberkamp, 2017), and there was no clear evidence that these measures were in fact protecting children and women, as they had been initially intended to do (Watson, 2011) A similar 'concern' was raised in EUROPOL's report that 'Romani criminal itinerant gangs' were abusing their children and women; yet there is no evidence that limiting the rights of Roma as EU citizens brought an improvement in the position of Romani women and children. The emergency response became a long-term policy towards remote Indigenous communities in the Northern Territory (Armillei and Lobo, 2017). To protect the human rights of the most vulnerable and to prevent criminal activities by some individuals in the community, entire communities were deprived of rights that non-Indigenous Australians take for granted.

The Intervention Act irregularised Indigenous people as Australian citizens, in a similar manner to how Roma have been irregularised as citizens in various European states. A few scholars have recognised the similarities between the Northern Territory Intervention and the so-called 'nomad emergencies' in Italy which occurred around the same time (Armillei and Lobo 2017; Hepworth 2012: 431). The emergency was called a 'nomad emergency' because it targeted Roma who were Bulgarian and Romanian citizens. Two additional parallels have remained under-analysed until now: first, although directly discriminatory emergency laws had been repealed, other manifestly more neutral laws took on the same function; and second, the political discourse around the Northern Territory Intervention constructed child abuse as a problematic part of aboriginality, that is, a key feature of Indigenous culture that needs to be controlled (Macoun, 2011). As in the case of Roma, it was the alleged problematic cultural practices of Indigenous people that were the basis for the violation of their citizenship rights and more general human rights (overriding the Racial Discrimination Act 1975 too).

\section{Conclusion}

This chapter has scrutinised concepts of ethical territoriality and irregularised citizenship. It has argued that whilst a number of 
countries are moving in the direction of ethical territoriality to extend certain citizenship rights to (some) aliens, they are also moving away from them by irregularising the status of some citizens. I have shown this through the example of Roma whose migration has been reinterpreted as a problematic cultural practice. I have argued that rather than looking at this through the lens of migration, we need to examine it through the prism of restricting citizenship rights. I have compared the restriction of free movement of Roma in Europe to the Northern Territory Intervention in Australia, which restricted certain rights for Indigenous communities by using the 'excuse' of protecting children and women from 'problematic' aboriginal culture. Previously, scholars have argued that there are different categories of citizenship and conceptualised them as semi-citizenship (Cohen, 2009). However, this chapter argues that the cases described do not simply correspond to citizens having different levels of rights. These are cases where citizens were supposed to have equal status but governments, through acts of sovereignty, irregularised their position. When critical voices have pointed out that the legal acts in question were racially discriminatory, states have usually transformed them so that they appear neutral but have kept the invisible edges of citizenship that position marginalised minorities at the fringes of their own citizenship. 